\title{
Fetal and adult liver stem cells for liver regeneration and tissue engineering
}

\author{
H. C. Fiegel a, *, Claudia Lange ${ }^{b}$, U. Kneser ${ }^{\text {, W. Lambrecht }}{ }^{\text {a }}$, \\ A. R. Zander ${ }^{b}$, X. Rogiers ${ }^{d}$, D. Kluth ${ }^{a}$ \\ a Pediatric Surgery, Universitätsklinikum Hamburg-Eppendorf, Hamburg, Germany \\ ${ }^{b}$ Bone Marrow Transplantation, Universitätsklinikum Hamburg-Eppendorf, Hamburg, Germany \\ c Plastic- and Hand-Surgery, University Hospital Erlangen, Germany \\ ${ }^{d}$ Hepatobiliary Surgery Universitätsklinikum Hamburg-Eppendorf, Hamburg, Germany
}

Received: March 23, 2006; Accepted: June 7, 2006

- Development of tissue engineering as a novel experimental approach for the treatment of liver diseases

- Identification and characterization of fetal liver (stem) cells

- Growth expansion and differentiation of fetal liver cells towards mature hepatocytes
- Use of adult liver stem cells for liver regeneration

- Differentiation of adult bone marrow derived MSC towards liver progenitor cells

- Finding the right stem cell candidate

- Development of tissue engineering and regeneration approach for liver diseases

- Conclusion

\begin{abstract}
For the development of innovative cell-based liver directed therapies, e.g. liver tissue engineering, the use of stem cells might be very attractive to overcome the limitation of donor liver tissue. Liver specific differentiation of embryonic, fetal or adult stem cells is currently under investigation. Different types of fetal liver (stem) cells during development were identified, and their advantageous growth potential and bipotential differentiation capacity were shown. However, ethical and legal issues have to be addressed before using fetal cells. Use of adult stem cells is clinically established, e.g. transplantation of hematopoietic stem cells. Other bone marrow derived liver stem cells might be mesenchymal stem cells (MSC). However, the transdifferentiation potential is still in question due to the observation of cellular fusion in several in vivo experiments. In vitro experiments revealed a crucial role of the environment (e.g. growth factors and extracellular matrix) for specific differentiation of stem cells. Co-cultured liver cells also seemed to be important for hepatic gene expression of MSC. For successful liver cell transplantation, a novel approach of tissue engineering by orthotopic transplantation of gel-immobilized cells could be promising, providing optimal environment for the injected cells. Moreover, an orthotopic tissue engineering approach using bipotential stem cells could lead to a repopulation of the recipients liver with healthy liver and biliary cells, thus providing both hepatic functions and biliary excretion. Future studies have to investigate, which stem cell and environmental conditions would be most suitable for the use of stem cells for liver regeneration or tissue engineering approaches.
\end{abstract}

Keywords: fetal stem cells - liver stem cells - mesenchymal stem cells - stem cell culture liver cell transplantation - hepatic tissue engineering

* Correspondence to: Henning C. FIEGEL, M.D.

Pediatric Surgery, Universitätsklinikum Hamburg-Eppendorf, Martinistrasse 52, D-20246 Hamburg, Germany.
Tel.: $+49.40 .42803 .6918 ;+49.40 .88908 .177$

Fax: +49.40 .42803 .6914$

E-mail: fiegel@uke.uni-hamburg.de 


\section{Development of tissue engineering as a novel experimental approach for the treatment of liver diseases}

Alternatives to organ transplantation for the treatment of certain liver diseases are currently under investigation. Whole organ liver, split-liver, and related livingdonor liver transplantation are clinically safe and well established procedures for the treatment of end-stage liver failure. However, donor organ shortage and the need of life-long immunosuppressive treatment are still the major limitations of all these options [1]. Therefore, the development of cell based therapeutic strategies for liver diseases are under ongoing experimental evaluation. Using cells instead of organs in this setting should permit $(i)$ expansion of cells in an in vitro phase, (ii) genetic or immunological manipulation of cells for transplantation, (iii) tissue typing and cryopreservation of cells for transplantation in a cell bank, and (iv) the genetic modification of patients own cells for autologuous transplantation $[2,3]$. In recent studies, a tissue engineering approach using isolated hepatocytes for in vitro tissue generation and heterotopic transplantation of liver cells has been established [4]. In this setting, a three dimensional matrix was used as a carrier for cell culture and transplantation of hepatocytes. Use of polymeric matrices permits the three dimensional formation of a neo-tissue and specific stimulation of the cells by special modification of the matrix-surface essential for appropriate differentiation of the cells $[5,6]$. In such a setting it was shown that coating the matrices with isolated ECM-molecules or modifying the matrices with matrix-bound releasable growth factors (e.g. FGF) could improve sufficient differentiation of hepatocytes [7, 8]. Additionally, culturing hepatocytes on three dimensional matrices permitted culture in a flow bioreactor system with increased function and survival of the cultured cells [9]. Hepatocytes on three dimensional matrices were easily transplanted into rats within the mesenteric leaves in a safe and reversible surgical procedure [10]. Heterotopic transplantation of hepatocytes on matrices allowed the transplantation of a cell number equivalent to a whole organ [11]. Further studies showed an efficient longterm engraftment of hepatocytes in a heterotopic location as well as a proliferation of the engrafted cells [12]. Heterotopically transplanted cells integrated functionally into the recipient and were metabolically active: in the glucuronyl-transferase deficient
Gunn rats and Vitamin-C deficient ODS rats a curative metabolic effect was observed after heterotopic transplantation of healthy hepatoctyes [13, 14]. However, though successfully establishing a model providing a combination of in vitro tissue generation and consecutive transplantation of liver cells, hepatocytes still showed only limited growth during culture period. Therefore, the use of highly proliferative cells could be an attractive alternative for improving these approaches. Up to now the formation of an artificial biliary system still remains a challenge in conventional tissue engineering approaches. Therefore, cells for hepatic tissue engineering should ideally be capable to differentiate at least bipotentially towards hepatocytic and biliary cells. In conclusion, the use of highly proliferative stem cells with a bipotential differentiation capacity towards liver cells or biliary cells would be very attractive for cell based alternative treatment approaches for liver diseases, providing $(i)$ expansion of donor or patients cells for transplantation during in vitro phase, (ii) genetic correction or immunologic modification of clonally growing patient cells, and (iii) formation of a functional liver tissue including a biliary system.

\section{Identification and characterization of fetal liver (stem) cells}

Different types of hepatic progenitors were identified during fetal liver development. In fetal mouse livers hepatic progenitors were isolated using fluorescence activated cell sorting (FACS) that exhibited typical features of hepatic stem cells: They showed clonogeneic potential in vitro, and had a bipotential differentiation capacity towards liver or biliary cells $[15,16]$. The phenotypic marker expression of these cells (c-kit-, CD49f+, CD29+, CD45-, TER119-) resembled that of more immature stem cells, lacking markers of the hepatocytic cell compartments of the fetal liver [17]. Another cell type identified in fetal rat livers was the "fetal liver epithelial progenitor cell" (FLEC) [18, 19]. Similar cells from the mouse also showed bipotential differentiation and a highly proliferative activity after transplantation into adult livers [20]. The marker expression of these cells showed typical features of immature hepatic cells (CK-19, AFP), however expression of stem cell markers remained 
Fig. 1 Method for isolation of fetal hepatic progenitor cells from developing rat liver. Fetal rat liver were harvested from rat fetusses at embryonal /fetal day (ED) 16,18 , or 20 . The liver tissue was digested and liver cells were isolated using an EGTA / collagenase digestion. By Magnetic cell sorting (MACS), OX-43 and OX-44 -positive hematopoietic cells of the fetal liver were removed and hepatic cells of the fetal liver were specifically enriched. In a second MACS-step the stem-cell marker Thy-1 positive cells were selected from the hepatic fetal liver cells.

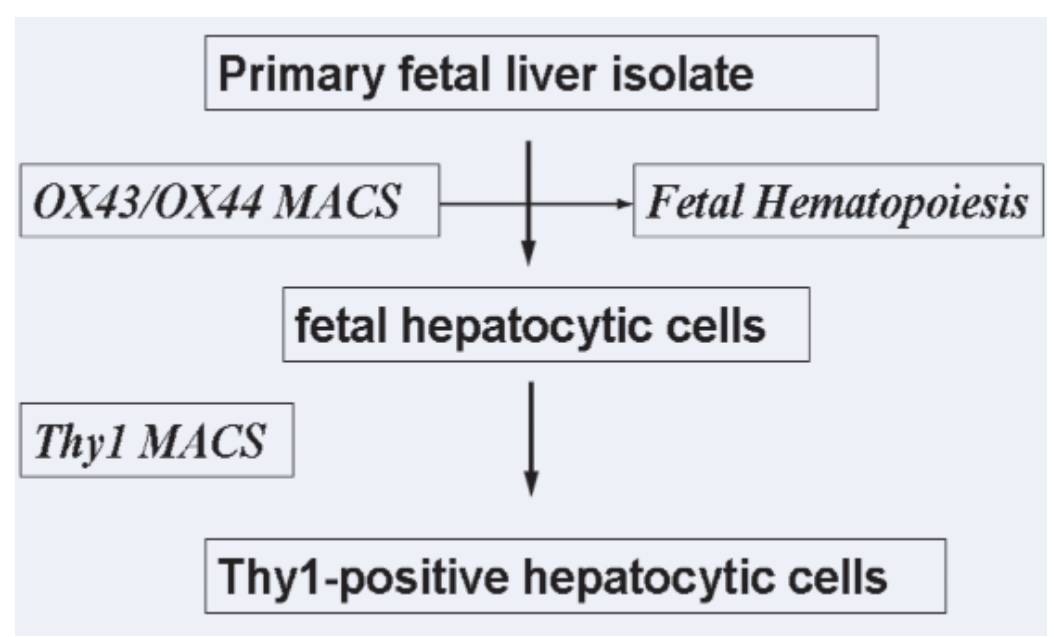

unknown. In the past the marker expression of different hepatic cell-compartments has been studied thoroughly in the adult liver. In a recent study, we identified different hepatic cell compartments already present during fetal liver development by immunocytochemical analysis: Co-existing in fetal liver cell isolates we found ( $i$ ) hepatic cells expressing CK-18, and (ii) hepatic cells simultaneously expressing CK-18 and Thy1 [21]. These cells resembled by their phenotypical marker expression stem cells of the adult liver (Oval cells), which showed typically co-expression of hepatocytic and biliary differentiation markers with markers well known from hematopoitic stem cells. [22-25]. Oval cells of the adult liver have a bipotential differentiation capacity towards hepatocytes or bile duct epithelial cells [26]; they are highly proliferative under certain conditions, and are clonogenic [27, 28]. Oval cells are involved in liver regeneration only under certain conditions, e.g. after combined liver damages or after activation by specific liver injury models [29, 30]. Cells co-expressing hematopoietic stem cell marker Thy1 and hepatic lineage marker CK-18 may represent early equivalents to the hepatic oval cell in the adult.

\section{Growth expansion and differentiation of fetal liver cells towards mature hepatocytes}

In a previous study, we isolated fetal liver cells by three steps (Fig. 1): (i) Collagenase/DNAse digestion and Percoll-purification, (ii) MACS-depletion of OX43/OX44 positive hematopoietic cells, and (iii) separation of Thy1-positive or Thy1-negative cells by MACS using Thy1 mAb [31]. RT-PCR analysis and immunocytochemical staining showed liver specific gene expression in double sorted Thy1-positive cells: In this compartment, we observed a constant CK18-RNA expression, a decreasing albumin-RNA expression, and an increasing of AFP-RNA expression in the late fetal period. Thus, Thy1-positive cells showed patterns of dedifferentiation towards the end of the fetal period, while Thyl-negative cells developed towards mature hepatocytes. After isolation of this cell type, in vitro experiments revealed a stemcell like growth potential of these cells. In a further study we investigated the growth and differentiation potential of isolated Thy1 positive or Thy1 negative cells in-vitro [32]. Thy1 positive cells from early fetal liver showed enormous growth (recovery $>$ $1600 \%$ ) which was significantly higher than the growth potential of Thyl negative cells from early fetal liver. Although the growth of Thy 1 positive cells was declining with maturation of the fetal liver, it was significantly higher in comparison to the growth of Thy 1 negative cells at all times. Thus, Thy 1 positive cells can be extensively expanded invitro. Immunocytochemistry and RT-PCR analysis showed that both Thyl positive cells and Thyl negative cells expressed the liver specific genes Cytokeratin 18 (CK18), alpha-feto protein (AFP), and albumin during the culture period [Fig. 2 A/B] Additionally, in an ongoing study we found, that highly proliferative fetal cells can be expanded serially by passage [Fig. 3]. The use of hepatic stem cells may become important for the improvement of tissue engineering approaches and cell-based therapeutic strategies for liver diseases. For such approaches hepatic stem cells may provide several advantages 

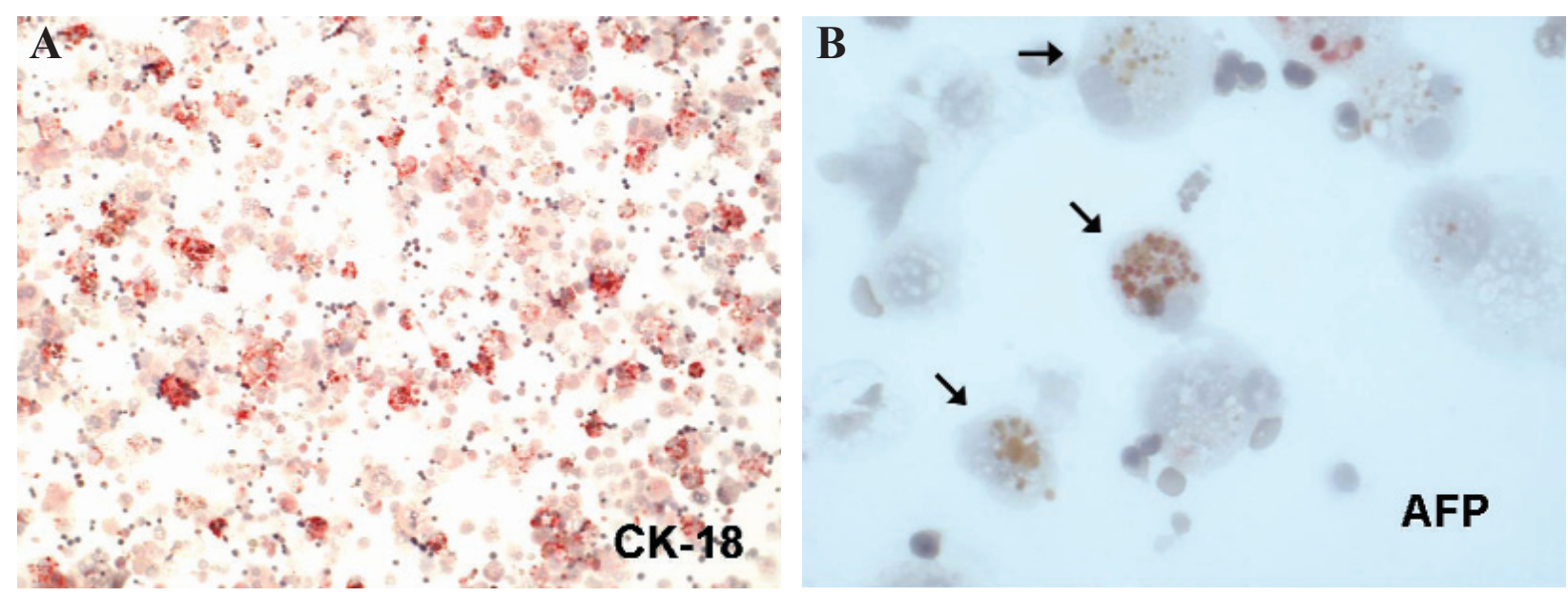

Fig. 2 Immuncytochemical analysis of cytospins from cultures of Thy-1 positive hepatic cells from ED 18 livers showed numerous cells positive for the liver epithelial cell specific Cytokeratin 18 (CK-18; A) and the immature liver cell marker alpha-feto-protein (AFP; B).

over hepatocytes: (i) Stem cells could be easily expanded, e.g. during a culture period, and (ii) transduction of stem cells may result in the expansion of "cured" daughter cells [29]. However, the role of fetal liver stem cells for new therapeutic applications has still to be defined; Besides the safety risks, ethical and legal aspects for the use of undifferentiated cells have to be evaluated with care [33].

\section{Use of adult liver stem cells for liver regeneration}

The existence of liver stem cells in the bone marrow was first demonstrated by Petersen et al., who showed that bone marrow cells transplanted into lethally irradiated mice engrafted in the recipients liver, and differentiated into liver stem cells (Oval cells) or mature liver cells (hepatocytes) [34]. These in vivo results were confirmed by mouse experiments [35], and in patients who received a bone marrow transplantation or peripheral blood stem cell transplantation for hematological disorders [36-38]. Furthermore, Lagasse et al. found liver specific gene-expression and function in FACS-sorted mouse hematopoietic stem cells (KTLS-cells: c-kithigh, thy $1^{+/}$, lin ${ }^{\text {neg, }}$ sca- $1^{+}$) after transplantation into FAH-deficient mice [39]. Recent data in the same animal model indicated that cells observed in the recipients liver after stem cell transplantation bearing donor markers and liver specific markers were rather a product of cell fusion than of a real "transdifferentiation" [40, 41]. However, variable data concerning cellular fusion versus transdifferentiation as the source of liver-like differentiated cells derived from bone marrow were found in other animal models: Engraftment of human albumin producing cells in livers of NOD/SCID recipient mice was observed after xenogeneic transplantation of human hematopoietic or umbilical cord blood stem cells; however, fusion events were not ruled out [42]. In contrast to this, two studies in a similar setting found liver specific differentiation of the transplanted cells occurring without any evidence for cell fusion events after transplantation of human sorted CD34+ or unsorted mononuclear cord blood cells into NOD/SCID mice [43, 44].

\section{Differentiation of adult bone marrow derived MSC towards liver progenitor cells}

First in vitro data suggested the differentiation potential of several types of bone marrow cells / stem cells towards hepatocytic cells under the appropriate culture conditions. Oh et al. found an expression of the liver specific genes AFP and albumin in cultures of unsorted rat bone marrow cells after 21 days. The liver specific gene expression was induced by the hepatocyte growth factor 
Fig. 3 Cell recovery curves of two examples of cultured hepatocytic fetal liver cells from ED 17 livers showed an enormous growth potential of the cells and an expansion of the cells enduring over several passages (P1, P2, and P3).

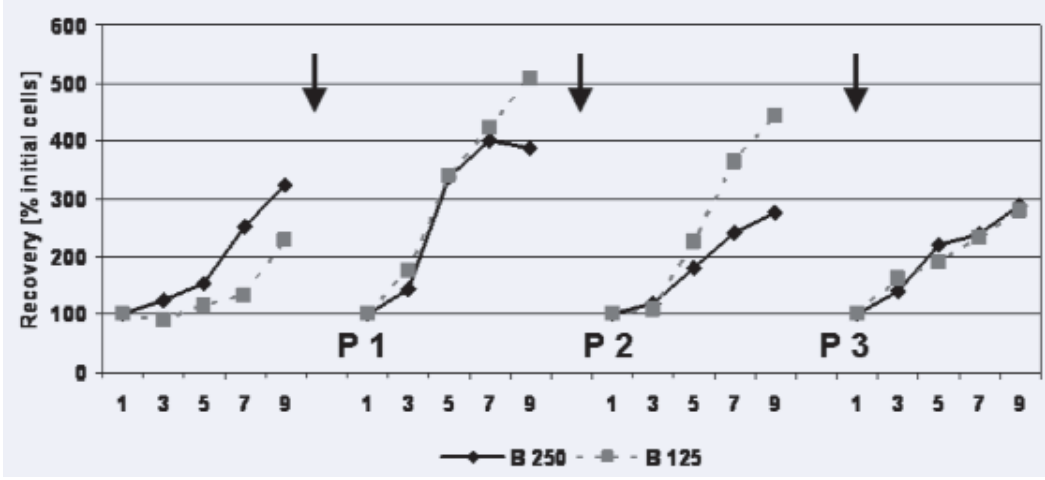

HGF, and was mediated by the expression of its receptor c-met [45]. The expression of liver specific genes (albumin, cytokeratins) in cultured human CD34-positive hematopoietic stem cells or mononuclear cord blood cells was also demonstrated to be induced by HGF in culture [46, 47]. Furthermore, Schwartz et al. isolated CD45 and Glycophorin A depleted multipotent adult progenitor cells (MAPC) from rat, mouse, or human plastic-adherent bone marrow cells that expressed liver specific markers after 14 days in culture with FGF and HGF, e.g. albumin and CK-18 [48]. From cultures of mature hepatocytes it is known, that important stimuli for an adequate cellular differentiation in vitro are $(i)$ the addition of growth hormones and cytokines to the culture medium $[49,50]$, (ii) coating culture dishes with extracel- lular matrix (ECM) molecules [51,5], and (iii) the co-culture with other cell types $[52,53]$. In stem cell cultures, Miyazaki et al. showed an induction of the liver specific genes albumin, tryptophan2,3-dioxygenase and tyrosine aminotransferase of rat bone marrow cells indicating a maturation towards hepatocytes, when cultured in a hepatocyte growth medium supplemented with HGF and epidermal growth factor EGF [54]. Avital et al. demonstrated, that $\beta 2 \mathrm{~m}$-negative thy1-positive stem cells residing in rat bone marrow expressed the liver marker albumin. In co-cultures of these cells with hepatocytes (separated by a PTFEmembrane) these cells were shown to adopt metabolic activity after 7 days in culture [55]. An important influence of hepatocytes on the differentiation of stem cell enriched bone marrow was

Fig. 4 Rat mesenchymal stem cells (MSC) from bone marrow were cocultured with adult hepatocytes for induction of liver specific differentiation. Clonally green-fluorescing protein (GFP) positive MSC were co-cultured with adult rat hepatocytes (Hepatocytes; GFP-negative) in a growth hormone supplemented culture medium and on a fibronectin-matrix. Cells from cocultures were isolated and sorted using fluorescence-activated cell sorting (FACS) to obtain GFP-positive or GFP-negative cells for PCRanalysis from the co-cultures.

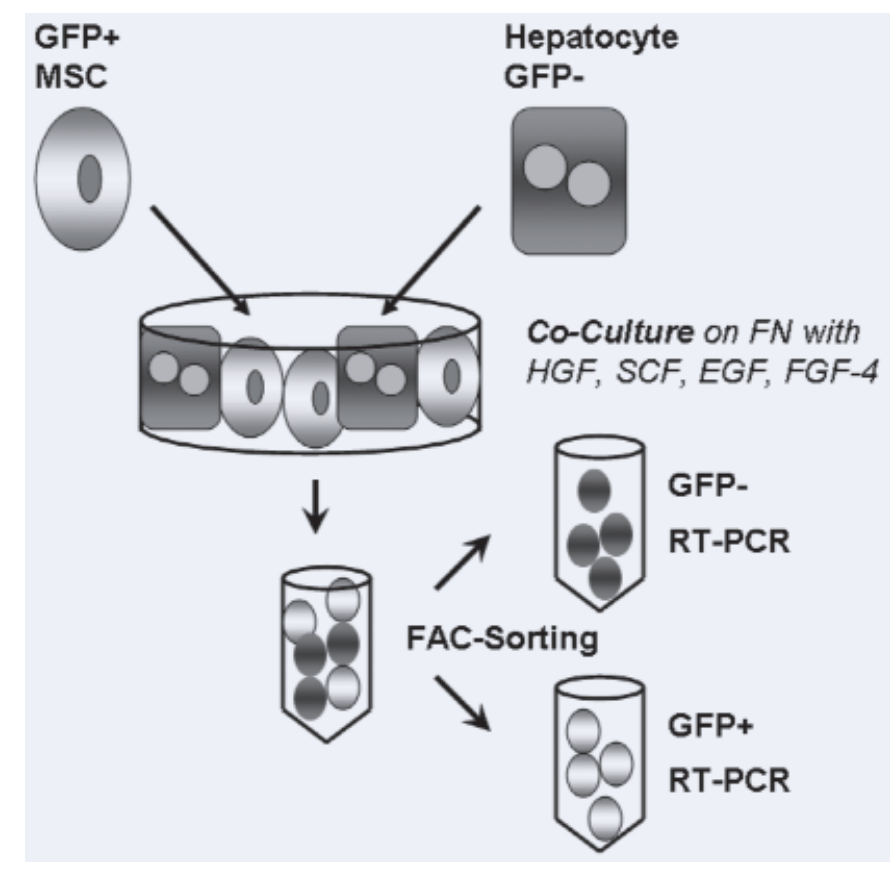



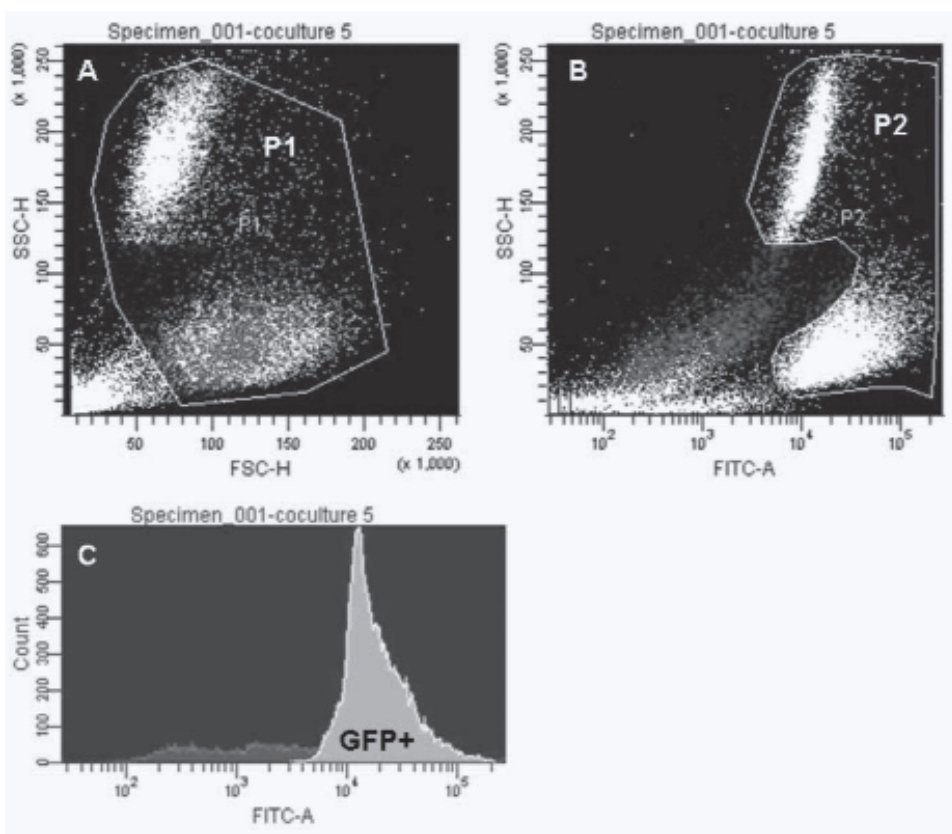

Fig. 5 One example from sorting of GFP+ and GFP- cells of cocultures at wk 1 is shown. (A) Viable cells were gated as P1. (B) P1 cells were gated in GFP- or $\mathrm{GFP}+(\mathrm{P} 2)$. (C) For highest purification of GFP+ cells, P2 was analyzed and only $\mathrm{GFP}+$ cells were sorted in the sample tube for PCR-analysis (light grey peak). also highlighted by Okumoto et al. MACSenriched bone marrow stem cells cultured in the presence of HGF and fetal bovine serum (FBS) alone expressed the markers hepatic nuclear factor 1 (HNF $1-\alpha)$ and CK-8 only after 7 days in culture. In cocultures with hepatocytes seperated by a semipermeable membrane the stem cells additionally expressed the liver specific markers AFP and albumin [56]. This suggested, that co-cultured hepatocytes have a stimulatory effect for the differentiation of stem cells towards liver cells, which was mediated by soluble factors. In a recent study by our group, GFP+ clones of rMSC from passage $\geq 9$ were used for the differentiation analysis towards liver cells. For liver specific differentiation, cells were cultured in co-cultures with liver cells. For gene-expression analysis, cells from co-cultures were separated in GFP-positive or GFP-negative cells by Fluorescence activated cell sorting before RT-PCR analysis (Fig. 4) [57]. We found that rMSC possess a differentiation potential towards hepatocytic cells in vitro: Expression of the liver specific genes e.g. albumin and CK-19 was demonstrated in GFP+ cells of the cocultures in vitro (Fig. $5 \mathrm{~A}-\mathrm{C}$ ). This suggested a further differentiation of rat MSC to mature hepatocytic cells, with a mixed phenotype between hepatic and biliary cells (Fig. 6) [58]. For other multipotential stem cell types from bone marrow also a hepatocytic differentiation poten- tial was shown by in vitro data: Sorted hematopoietic stem cells $[55,46]$, multipotential adult progenitor cells [48], or side population cells in the liver derived from bone marrow [59] were found to express liver specific genes, when cultured in the presence of growth factors. Our and other studies provide growing evidence that MSC possessed a differentiation potential towards hepatocytic cells, or at least liver stem like cells [60-62]. Additionally, we could show that for induction of liver specific gene expression co-culture of hepatocytes played a pivotal role.

\section{Finding the right stem cell candidate}

Bone-marrow derived liver stem cells, especially MSC are promising candidates for new cell-based approaches for the treatment of liver diseases [63]: (a) these cells can be easily harvested from adult bone marrow and expanded tremendiously in vitro; (b) transduction of MSC may result in the expansion of "cured" daughter cells; (c) the use of adult stem cells is favourable over other stem cells, such as embryonic stem cells or fetal stem cells, regarding ethical issues. The differentiation of such cells towards liver cells by co-cultures may permit the generation of artificial liver tissue for tissue engineering of the liver, or liver cell 
Fig. 6 Reverse-transcription polymerase chain reaction (RTPCR) of the GFP+ MSC-derived cells showed a gene expression of the hepatocyte specific marker albumin (ALB) and the biliary cell specific marker Cytokeratin-19 (CK-19) after two weeks in the cocultures. Cocultured GFP- hepatocytes also expressed both markers in the cocultures, hepatocyte-controls expressed ALB, whereas cultures of rMSC alone did not show hepatic genes ALB or CK-19.
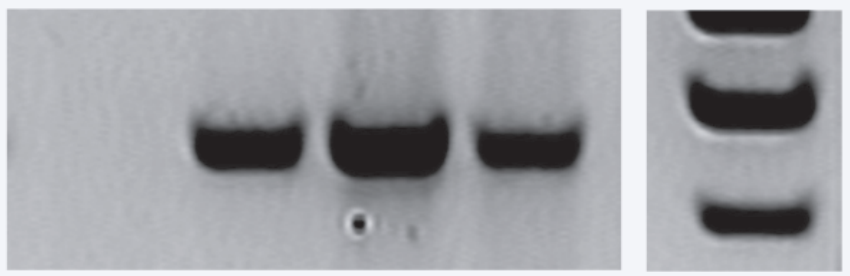

ALB
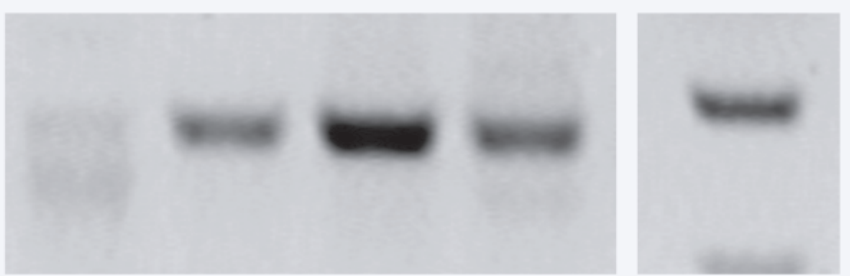

CK19

\section{rMSC rHEP GFP- GFP+ Marker}

transplantation [64]. Thus, the potential of MSC to differentiate towards functional liver cells should be of high interest for new cell-based therapies.

\section{Development of tissue engineering and regeneration approach for liver diseases}

For any clinical application of hepatocyte transplantation, a safe mode of supportive orthotopic cell transplantation into the liver would be desir- able that avoids the observed side effects of intraportal injection. In a recent study we aimed to evaluate fibrin glue as a novel matrix for culture and orthotopic extravascular transplantation of hepatocytes. Fibrin glue is developed for tissue repair and hemostasis. It is a well established tool in general surgery and minimises blood loss during major procedures such as partial liver resection [65-67]. Fibrin gel has been used in experimental settings as a matrix for culture and transplantation of several cell types, e.g. cartilage,
Fig. 7 Injectable liver: Rat hepatocytes were harvested from adult rat livers by two step collagenase digestion. Isolated cells were marked with the fluorescence dye pkh-26 and were injected within an in-situ setting gel matrix based on fibrinogen and thrombin (two component fibrin-glue) directly in the recipient's liver parenchyma.

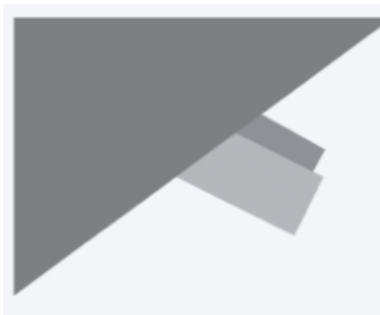

Hepatocyte Isolation
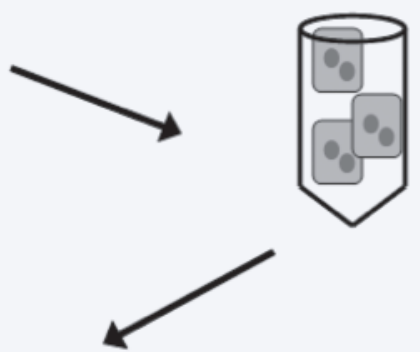

Labelling with

Pkh 26

\section{Direct orthotopic cell injection within two component matrix}



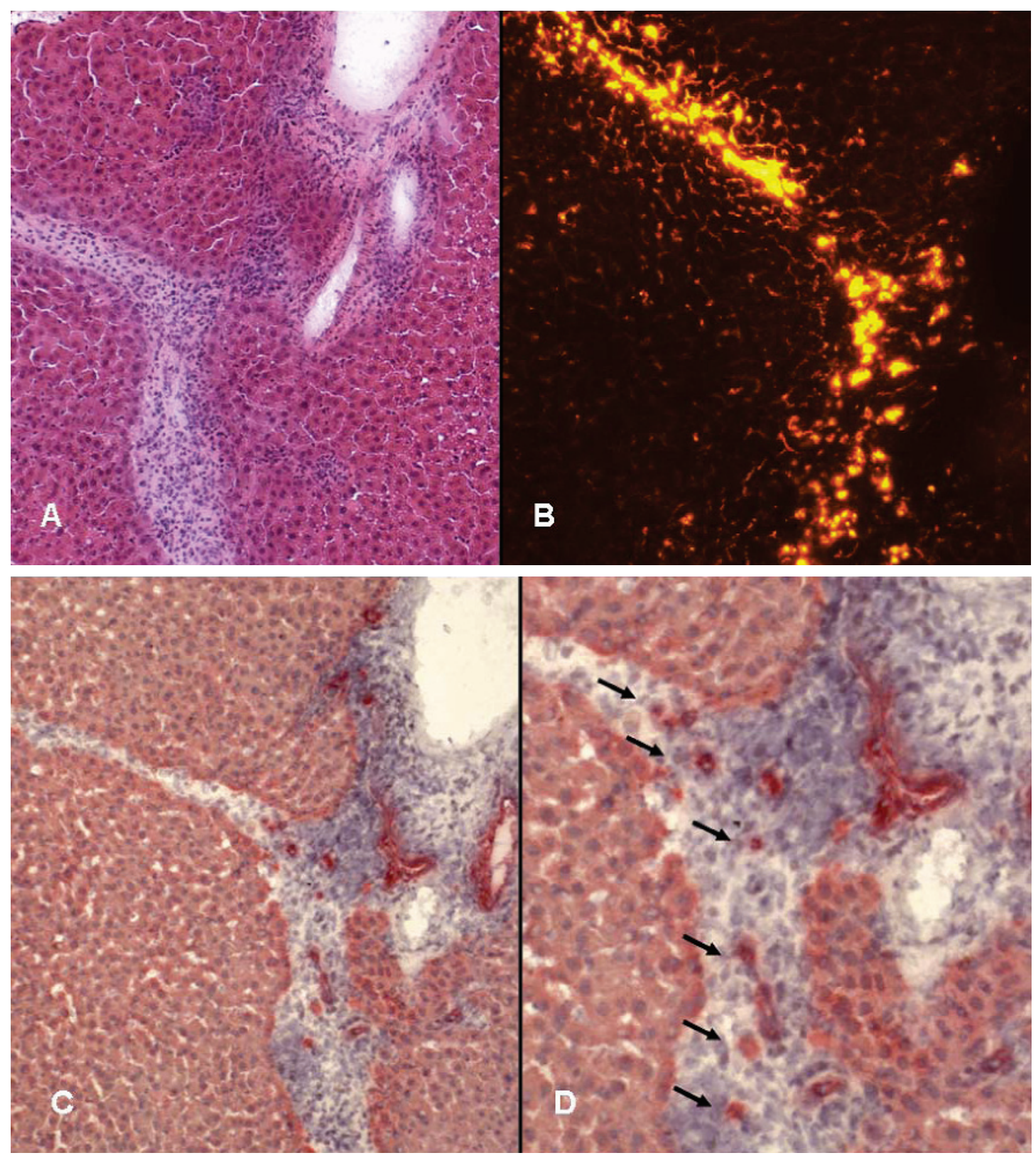

Fig. 8 HE-staining of the explanted recipient livers 7 days after cell injection showed a fibrin-clot in degradation with engrafted cells at the site of transplantation (A). Under fluorescenc-light, the transplanted cells were easily identified by their positivity for the pkh-26 dye labelling (B; yellow cells). Immunocytochemistry of a serial section for the hepatocyte specific cytokeratin 18 (CK-18) showed viable engrafted CK-18 positive hepatocyte within the fibrin-matrix (C; detail $\mathbf{D}$ : arrows mark positive cells).

bone and urothelial cells [68-70]. Fibrin gel allows as a two-component in situ setting matrix the minimal invasive application of different cell types of tissues. We could show an efficient engraftment of donor derived hepatocytes and non-parenchymal liver cells in the recipients liver 
by fibrin-matrix based transplantation recently (Fig. 7) [71]. A week after transplantation, the fibrin clot apparently was degraded. CK-18 positive donor hepatocytes were well engrafted within the parenchyma. The histological data provided evidence, that there is an active integration of the transplanted cells in the recipient liver parenchyma, with a high proportion of non-parenchymal liver cells (Fig. 8). The fibrin matrix was consecutively resorbed by donor cells within days. We suggest that "injectable liver" using a fibrin matrix as carrier for liver cells represents a safe way for application of a sufficient cell mass orthotopically into a favorable environment. Furthermore, it appears to support engraftment and specific differentiation of viable hepatocytes (Fig. 8). Thus, the results are encouraging that fibrin glue is a suitable matrix for orthotopic transplantation of hepatocytes and stem cell candidates. This "injectable liver" -approach may represent an improved carrier for cell-based therapeutic approaches for liver diseases.

\section{Conclusion}

The use of stem cells for liver directed cell-based therapeutic approaches should be very attractive. However, the mechanism for generation of liver cells by stem cells remains still controversial, and in vivo results showed a very low repopulation of the liver by stem cells. Therefore, the development of appropriate methods of cell transplantation is mandatory in order to improve successful repopulation and tissue engineering approaches for liver therapy by stem cells. Furthermore, studies have to show which stem cells (e.g. adult bone marrow derived, fetal organ derived) are superior to use for the formation of functional liver tissue for tissue / organ repair.

\section{Acknowledgements}

The authors would like to thank the medical students Christina Höper, Jana Ahrend, Daniel Schultze and Helge Bruns for their excellent laboratory work, and Beate Roth and Arne Düsedow for technical assistance.

\section{References}

1. Keeffe EB. Liver transplantation: Current status and novel approaches to liver replacement. Gastroenterology 2001; 120: 749-62.

2. Bianco P, Robey PG. Stem cells in tissue engineering. Nature 2001; 414: 118-21.

3. Malhi H, Gupta S. Hepatocyte transplantation: new horizons and challenges. J Hepatobiliary Pancreat Surg. 2001; 8: 40-50.

4. Kaufmann PM, Sano K, Uyama S, Schloo B, Vacanti JP. Heterotopic hepatocyte transplantation using threedimensional polymers: evaluation of the stimulatory effects by portocaval shunt or islet cell cotransplantation. Transplant Proc. 1994; 26: 3343-5.

5. Mooney D, Hansen L, Vacanti J, Langer R, Farmer S, Ingber D. Switching from differentiation to growth in hepatocytes: Control by extracellular matrix. J Cell Physiol. 1992; 151: 497-505.

6. Mooney DJ, Park S, Kaufmann PM, Sano K, McNamara K, Vacanti JP, Langer R. Biodegradable sponges for hepatocyte transplantation. J Biomed Mater Res. 1995; 29: 959-65.

7. Kaufmann PM, Heimrath S, Kim BD, Mooney DJ. Highly porous polymer matrices as three dimensional culture system for hepatocytes. Cell Transplant. 1997; 6: 463-8.

8. Lee H, Cusick RA, Browne F, Kim TH, Ma PX, Utsunomiya H, Langer R, Vacanti JP. Local delivery of basic fibroblast growth factor increases both angiogenesis and engraftment of hepatocytes in tissue-engineered polymer devices. Transplantation 2002; 73 : 1589-93.

9. Fiegel HC, Havers J, Kneser U, Smith MK, Moeller T, Kluth D, Mooney DJ, Rogiers X, Kaufmann PM. Influence of flow conditions and matrix coatings on growth and differentiation of three-dimensionally cultured rat hepatocytes. Tissue Eng 2004; 10: 165-74.

10. Kneser U, Kaufmann PM, Fiegel HC, Pollok JM, Kluth D, Herbst H, Rogiers X. Heterotopic hepatocyte transplantation utilizing pancreatic islet cotransplantation for hepatotrophic stimulation: morphologic and morphometric evaluation. Pediatr Surg Int 1999; 15: 168-74.

11. Uyama S, Kaufmann PM, Takeda T, Vacanti JP. Delivery of whole liver-equivalent hepatocyte mass using polymer devices and hepatotrophic stimulation. Transplantation 1993; 55: 932-5.

12. Kneser U, Kaufmann PM, Fiegel HC, Pollok JM, Kluth D, Herbst H, Rogiers X. Long-term differentiated function of heterotopically transplanted hepatocytes on three dimensional polymer matrices. J Biomed Mater Res 1999; 47: 494.

13. Asonuma K, Gilbert JC, Stein JE, Takeda T, Vacanti JP. Quantitation of transplanted hepatic mass necessary to cure the Gunn rat model of hyperbilirubinemia. $J$ Pediatr Surg 1992; 27: 298-301.

14. Uyama S, Kaufmann PM, Kneser U, Fiegel HC, Pollok JM, Kluth D, Vacanti JP, Rogiers X. Hepatocyte trans- 
plantation using biodegradable matrices in ascorbic aciddeficient rats: comparision with heterotopically transplanted liver grafts. Transplant 2001; 71: 1226-31.

15. Suzuki A, Zheng YW, Kondo R, Kusakabe M, Takada Y, Fukao K, Nakauchi H, Taniguchi H. Flowcytometric separation and enrichment of hepatic progenitor cells in the developing mouse liver. Hepatology 2000; 32: 1230-9.

16. Taniguchi H, Suzuki A, Zheng Y, Kondo R, Takada Y, Fukunaga K, Seino K, Yuzawa K, Otsuka M, Fukao K, Nakauchi H. Usefulness of flowcytometric cell sorting for the enrichment of hepatic stem and progenitor cells in the liver. Transplant Proc. 2000; 32: 249-51.

17. Suzuki A, Zheng YW, Kaneko S, Onodera M, Kukao K, Nakauchi H, Taniguchi H. Clonal identification and characterization of self-renewing pluripotent stem cells in the developing liver. J Cell Biol. 2002; 156: 173-84.

18. Dabeva MD, Petkov PM, Sandhu J, Oren R, Laconi E, Hurston E, Shafritz DA. Proliferation and differentiation of fetal liver epithelial progenitor cells after transplantation in the rat liver. Am J Pathol. 2000; 156: 2017-31.

19. Sandhu JS, Petkov PM, Dabeva MD, Shafritz DA. Stem cell properties and repopulation of the rat liver by fetal liver epithelial progenitor cells. Am J Pathol. 2001; 159: 1323-34.

20. Nierhoff D, Ogawa A, Oertel M, Chen YQ, Shafritz DA. Purification and characterization of mouse fetal liver epithelial cells with high in vivo repopulation capacity. Hepatology 2005; 42: 130-9.

21. Fiegel HC, Park JH, Lioznov MV, Martin A, Jaeschke-Melli S, Kaufmann PM, Fehse B, Zander AR, Kluth D. Characterization of cell types during rat liver development. Hepatology 2003; 37: 148-54.

22. Thorgeirsson SS. Liver regeneration 9: Hepatic Stem cells in liver regeneration. FASEB J. 1996; 10: 1249-56.

23. Michalopoulos GK, DeFrances MC. Liver regeneration. Science 1997 ; 276: 60-6.

24. Strain AJ, Crosby HA. Hepatic stem cells. Gut 2000; 46: $743-5$.

25. Vessey CJ, de la Hall PM. Hepatic stem cells. Pathology 2001; 33: 130-41.

26. Haruna Y, Saito K, Spaulding S, Nalesnik MA, Gerber MA. Identification of bipotential progenitor cells in human liver development. Hepatology 1996; 23: 476-81.

27. Lazaro CA, Rhim JA, Yamada Y, Fausto N. Generation of hepatocytes from oval cell precursors in culture. Cancer Res. 1998; 58: 5514-22.

28. Evarts RP, Nagy P, Marsden E, Thorgeirsson SS. A precursor-product relationship exists between oval cells and hepatocytes in rat liver. Carcinogenesis 1993; 8: 1737-40.

29. Thorgeirsson SS, Evarts RP, Bisgaard HC, Fujio K, Hu Z. Hepatic stem cell compartment: activation and lineage commitment. Proc Soc Exp Biol Med. 1993; 204: 253-60.

30. Petersen BE, Zajak VF, Michalopoulos GK. Hepatic oval cell activation in response to injury following chemically induced periportal or pericentral damage in rats. Hepatology 1998; 27: 1030-8.
31. Fiegel HC, Kluth J, Lioznov MV, Holzhuter S, Fehse B, Zander AR, Kluth D. Hepatic lineages isolated from developing rat liver show different ways of maturation. Biochem Biophys Res Comm. 2003; 305: 46-53.

32. Fiegel HC, Bruns H, Hoper C, Lioznov MV, Kluth D. Cell growth and differentiation of different hepatic cells isolated from fetal rat livers in vitro. Tissue Eng 2006; 12: $123-30$.

33. McLaren A. Ethical and social considerations of stem cell research. Nature 2001; 414: 129-31.

34. Petersen BE, Bowen WC, Patrene KD, Mars WM, Sullivan AK, Murase N, Boggs SS, Greenberger JS, Goff JP. Bone marrow as a potential source of hepatic oval cells. Science 1999; 284: 1168-70.

35. Theise ND, Badve S, Saxena R, Henegariu O, Sell S, Crawford JM, Krause DS. Derivation of hepatocytes from bone marrow cells in mice after radiation induced myeloablation. Hepatology 2000; 31: 235-40.

36. Alison MR, Poulsom R, Jeffery R, Dhillon AP, Quaglia A, Jacob J, Novelli M, Prentice G, Williamson J, Wright NA. Hepatocytes from non-hepatic adult stem cells. Nature 2000; 406: 257.

37. Theise ND, Nimmakayalu M, Gardner R, Illei PB, Morgan G, Teperman L, Henegariu O, Krause DS. Liver from bone marrow in humans. Hepatology 2000; 32: 11-6.

38. Korbling M, Katz RL, Khanna A, Ruifrok AC, Rondon G, Albitar M, Champlin RE, Estrov Z. Hepatocytes and epithelial cells of donor orighin in the recipients of peripheral blood stem cell transplantation. N Engl J Med. 2002 ; 346: 738-46.

39. Lagasse E, Connors H, Al-Dhalimy M, Reitsma M, Dohse $M$, Osborne L, Wang $X$, Finegold $M$, Weissman IL, Grompe M. Purified hematopoietic stem cells can differentiate into hepatocytes in vivo. Nature Med 2000; 6: 1229-34.

40. Wang X, Willenbring H, Akkari Y, Torimaru Y, Foster M, Al-Dhalimy M, Lagasse E, Finegold M, Olson S, Grompe M. Cell fusion is the principal source of bone marrow derived hepatocytes. Nature 2003; 422: 897-901.

41. Vassilopoulos G, Wang PR, Russell DW. Transplanted bone marrow regenerates liver by cell fusion. Nature 2003; 422: 901-4.

42. Wang X, Ge S, McNamara G, Hao QL, Crooks GM, Nolta JA. Albumin-expressing hepatocyte-like cells develop in the livers of immune-deficient mice that received transplants of highly purified human hematopoietic stem cells. Blood 101, 2003: 4201-8.

43. Ishikawa F, Drake CJ, Yang S, Fleming P, Minamiguchi H, Visconti RP, Crosby CV, Argraves WS, Harada M, Key LL Jr, Livingston AG, Wingard JR, Ogawa M. Transplanted human cord blood cells give rise to hepatocytes in engrafted mice. Ann N Y Acad Sci. 2003: 996: 174-85.

44. Newsome PN, Johannessen I, Boyle S, Dalakas E, McAulay KA, Samuel K, Rae F, Forrester L, Turner ML, Hayes PC, Harrison DJ, Bickmore WA, Plevris JN. Human cord blood-derived cells can differentiate into hepatocytes in the mouse liver with no evidence of cellular fusion. Gastroenterology 2003; 124: 1891-900. 
45. Oh SH, Miyazaki M, Kouchi H, Inoue Y, Sakaguchi M, Tsuji T, Shima N, Higashio K, Namba M. Hepatocyte growth factor induces differentiation of adult rat bone marrow cells into hepatocyte lineage in vitro. Biochem Biophys Res Comm. 2000; 279: 500-4.

46. Fiegel HC, Lioznov MV, Cortes-Dericks L, Lange C, Kluth D, Fehse B, Zander AR. Liver specific gene expression in cultured human hematopoietic stem cells. Stem Cells 2003; 21: 98-104.

47. Kakinuma S, Tanaka Y, Chinzei R, Watanabe M, Shimizu-Saito K, Hara Y, Teramoto K, Arii S, Sato C, Takase K, Yasumizu T, Teraoka H. Human umbilical cord blood as source of transplantable hepatic progenitor cells. Stem Cells 2003; 21: 217-27.

48. Schwartz RE, Reyes M, Koodie L, Jiang Y, Blackstad M, Lund T, Lenvik T, Johnson S, Hu WS, Verfaillie CM. Multipotent adult progenitor cells from bone marrow differentiate into functional hepatocyte-like cells. $J$ Clin Invest. 2002; 109: 1291-302.

49. Block GD, Locker J, Bowen WC, Petersen BE, Katyal S, Strom SC, Riley T, Howard TA, Michalopoulos GK. Population expansion, clonal growth, and specific differentiation patterns in primary cultures of hepatocytes induced by HGF/SF, EGF, and TGF alpha in an chemically defined (HGM) medium. $J$ Cell Biol. 1996; 132: 1133-49.

50. Reid LM. Stem cell biology, hormone/matrix synergies and liver differentiation. Curr Opin Cell Biol. 1990; 2: 121-30.

51. Berthiaume F, Moghe PV, Toner M, Yarmush ML. Effect of extracellular matrix topology on cell structure, function, and physiological responsiveness: hepatocytes cultured in a sandwich configuration. FASEB J 1996; 10: 1471-84.

52. Guguen-Guillouzo C, Clement B, Baffet G, Beaumont C, Morel-Chany E, Glaise D, Guillouzo A. Maintenance and reversibility of active albumin secretion by adult rat hepatocytes co-cultured with another liver epithelial cell type. Exp Cell Res 1983; 143: 47-54.

53. Shimaoka S, Nakamura T, Ichihara A. Stimulation of growth of primary cultured adult rat hepatocytes without growth factors by coculture with nonparenchymal liver cells. Exp Cell Res. 1987; 172: 228-42.

54. Miyazaki M, Akiyama I, Sakaguchi M, Nakashima E, Okada M, Kataoka K, Huh NH. Improved conditions to induce hepatocytes from rat bone marrow cells in culture. Biochem Biophys Res Comm. 2002; 298: 24-30.

55. Avital I, Inderbitzin D, Aoki T, Tyan DB, Cohen AH, Ferraresso C, Rozga J, Arnaout WS, Demetriou AA. Isolation, characterization, and transplantation of bone marrow derived hepatocyte stem cells. Biochem Biophys Res Comm. 2001; 288: 156-64.

56. Okumoto K, Saito T, Hattori E, Ito JI, Adachi T, Takeda T, Sugahara K, Watanabe H, Saito K, Togashi H, Kawata S. Differentiation of bone marrow cells into cells that express liver-specific genes in vitro: implication of the Notch signals in differentiation. Biochem Biophys Res Comm 2003; 304: 691-5.

57. Lange C, Bassler P, Lioznov MV, Bruns H, Kluth D, Zander AR, Fiegel HC. Hepatocytic gene expression in cultured rat mesenchymal stem cells. Transplant Proc. 2005; 37: 276-9.
58. Lange C, Bassler P, Lioznov MV, Bruns H, Kluth D, Zander AR, Fiegel HC. Liver-specific gene expression in mesenchymal stem cells is induced by liver cells. World J Gastroenterol. 2005; 11: 4497-504.

59. Wulf GG, Luo KL, Jackson KJA, Brenner MK, Goodell MA. Cells of the hepatic side population contribute to liver regeneration and can be replenished by bone marrow stem cells. Haematologica 2003; 88: 368-78.

60. Shu SN, Wei L, Wang JH, Zhan YT, Chen HS, Wang Y. Hepatic differentiation capability of rat bone marrowderived mesenchymal stem cells and hematpoietic stem cells. World J Gastroenterol. 2004; 10: 2818-22.

61. Kang XQ, Zang WJ, Song TS, Xu XL, Yu XJ, Li DL, Meng KW, Wu SL, Zhao ZY. Rat bone marrow mesenchymal stem cells differentiate into hepatocytes in vitro. World J Gastroenterol 2005; 11: 3479-84.

62. Lee KD, Kuo TK, Whang-Peng J, Chung YF, Lin CT, Chou SH, Chen JR, Chen YP, Lee OK. In vitro hepatic differentiation of humen mesenchymal stem cells. Hepatology 2004; 40: 1275-84.

63. Mitaka T. Hepatic stem cells: from bone marrow cells to hepatocytes. Biochem Biophys Res Comm. 2001; 281: $1-5$.

64. Mitaka T. Reconstruction of hepatic organoid by hepatic stem cells. J Hepatobiliary Panceat Surg. 2002; 9: 697-703.

65. Nakajima Y, Shimamura T, Kamiyama T, Matsushita M, Sato N, Todo S. Control of intraoperative bleeding during liver resection: analysis of a questionaire sent to 231 Japanese hospitals. Surg Today 2002; 32: 48-52.

66. Ochsner MG, Maniscalco-Theberge ME, Champion HR. Fibrin glue as a hemostatic agent in hepatic and splenic trauma. J Trauma. 1990; 30: 884-7.

67. Feinstein AJ, Varela JE, Cohn SM, Compton PR, McKenney MG. Fibrin glue eliminates the need for packing after complex liver injuries. Yale J Biol Med 2001; 5: 315-21.

68. Xu JW, Zaporojan V, Peretti GM, Roses RE, Morse KB, Roy AK, Mesa JM, Randolph MA, Bonassar LJ, Yaremchuk MJ. Injectable tissue-engineered cartilage with different chondrocyte sources. Plast Reconstr Surg. 2004; 113: 1361-71.

69. Wechselberger G, Russell RC, Neumeister MW, Schoeller T, Piza-Katzer H, Rainer C. Successful transplantation of three tissue engineered cell types using capsule induction technique and firbin glue as a delivery vehicle. Plast Reconstr Surg. 2002; 110: 123-9.

70. Stangenberg L, Schaefer DJ, Buettner O, Ohnolz J, Mobest D, Horch RE, Stark GB, Kneser U. Differentiation of osteoblasts in three-dimensional culture in processed cancellous bone matrix: quantitative analysis of gene expression based on real-time RT-PCR. Tissue Eng. 2005; 11: 855-64.

71. Bruns H, Kneser U, Holzhuter S, Roth B, Kluth J, Kaufmann PM, Kluth D, Fiegel HC. Injectable liver: a novel approach using fibrin gel as a matrix for culture and intrahepatic transplantation of hepatocytes. Tissue Eng. 2005; 11: 1718-26. 